\title{
Role of the corpus luteum of pregnancy in controlling pituitary gonadotrophin secretion during the early post-partum period in the ewe
}

\author{
K. H. Al-Gubory, M. R. Blanc* and J. Martinet \\ I.N.R.A.-Unité d'Endocrinologie Cellulaire et Moléculaire, 78350 Jouy-en-Josas, France; and \\ *I.N.R.A. Laboratoire de Neuroendocrinologie, 37380 Nouzilly, France
}

\begin{abstract}
Summary. No difference was found between 5 intact ewes and 5 ewes from which the CL had been excised at Day 70 of pregnancy in the plasma concentration of progesterone at Day 140, and concentrations of progesterone remained below $0.2 \mathrm{ng} / \mathrm{ml}$ during the first 20 days post partum. Plasma concentrations of $L H$, frequency and amplitude of LH pulses were low at Day 140 and increased considerably, particularly in the CLexcised ewes, as early as Day 5 post partum. No significant differences were found between the two groups of ewes in the mean plasma concentrations of FSH for any of the 5 stages examined. Taken together, these results suggest that some factor, other than progesterone, associated with the CL of pregnancy is involved in the inhibition of pulsatile LH secretion during the early post-partum period.
\end{abstract}

Keywords: ewe; pregnancy; post partum; corpus luteum; pituitary gonadotrophins

\section{Introduction}

In all mammalian species, the corpus luteum (CL) secretes progesterone which is required for the establishment and maintenance of pregnancy. In sheep, as early as Day 50 and in the absence of ovaries (Casida \& Warwick, 1945; Neher \& Zarrow, 1954; Denamur \& Martinet, 1955) the placenta secretes progesterone (Linzell \& Heap, 1968) in amounts sufficient for pregnancy maintenance (Moore et al., 1972; Ricketts \& Flint, 1980). The luteotrophic support of pituitary prolactin and LH (Denamur \& Martinet, 1961; Denamur, 1968; Kann \& Denamur, 1974) and the antiluteolytic effect of the conceptus (Moor \& Rowson, 1966a, b; Rowson \& Moor, 1967; Moor, 1968; Ellinwood et al., 1979; Martal et al., 1979; Heyman et al., 1984) ensure CL activity and maintenance of early pregnancy. Hypophysectomy performed between Days 50 and 134 of pregnancy does not cause abortion (Denamur \& Martinet, 1961). During that time, the feto-placental unit secretes luteotrophic factors with prolactin (Forsyth, 1973; Martal \& Djiane, 1975, 1977) and LH (Lacroix \& Martal, 1979) -like activity which appear to be implicated in the prolongation of the life of the CL to term (Martal \& Lacroix, 1978; Martal, 1981).

Despite these extensive studies, little is known about the physiological role of the CL during the last two-thirds of pregnancy in ewes. When the CL are not necessary for pregnancy maintenance, they affect, both locally (Al-Gubory \& Martinet, 1987) and systemically (Al-Gubory et al., 1987), early follicle development. Excision of the CL at Day 70 of pregnancy results in increasing plasma concentrations of $\mathrm{LH}$, frequency and amplitude of LH pulses but is without effect on plasma concentrations of FSH and progesterone (Al-Gubory et al., 1989). These results suggest that some luteal factor, presumably not progesterone, contributes selectively to the inhibition of LH secretion during the last two-thirds of pregnancy.

This finding prompted us to examine the effect of removal of the CL at mid-pregnancy on subsequent secretion of pituitary gonadotrophins during the early post-partum period. 


\section{Materials and Methods}

Experimental animals. Ewes of the Préalpes du Sud breed were induced to ovulate with 400 i.u. PMSG and mated during the month of July so that lambing would occur during the breeding season (December). At Day 70 of pregnancy, 10 ewes were initially anaesthetized with a mixture of $120 \mathrm{mg}$ pentobarbitone sodium (Sanofi, Paris, France) and $400 \mathrm{mg}$ thiopentone sodium (Abbott, Auberviliers, France), and anaesthesia was maintained by inhalation of a mixture of halothane-oxygen. Mid-ventral laparotomy was performed and corpora lutea were removed, as described previously (Al-Gubory et al., 1989), from 5 ewes (Group L) selected randomly. The 5 other ewes (Group C controls) were sham-operated. In the two groups of ewes, the number of CL present in each ovary was noted at laparotomy. All ewes were injected intramuscularly with penicillin ( $10^{6} \mathrm{U}$ per day) for 3 consecutive days after surgery.

Blood sampling. For FSH and LH determination, jugular blood samples were collected from each animal at 20 min intervals for a 7-h period beginning at 09:00 h using evacuated heparinized tubes (Becton-Dickinson, Meylan, France) at Day 140 of pregnancy and on Days 5, 10, 15 and 20 post partum. For progesterone determination, blood samples were taken from each animal by jugular venepuncture at 09:00 h every 2 days between Day 140 of pregnancy and Day 20 post partum. The plasma was obtained by centrifugation $\left(3000 \mathrm{~g}\right.$ at $\left.4^{\circ} \mathrm{C}\right)$, frozen and stored at $-20^{\circ} \mathrm{C}$ until assayed. Suckling lengthens the interval of post-partum anoestrus (Mauléon \& Dauzier, 1965), increases prolactin (Kann \& Martinet, 1975) and decreases LH (Restall \& Starr, 1977) secretion in ewes. Therefore, to eliminate any possible effect of suckling on the secretion of gonadotrophins, the lambs were removed immediately after parturition.

Hormone assays. Plasma concentrations of LH and FSH were measured by a double-antibody radioimmunoassay (RIA) described and proven specific for sheep LH and FSH (Pelletier et al., 1968; Blanc \& Poirier, 1979) using NIHLH-S1 and NIH-FSH-S3 as standards. To avoid inter-assay variations, all plasma samples were run in duplicate in a single assay for each hormone. The intra-assay coefficient of variation was $<12 \%$ and $<10 \%$ respectively for $\mathrm{LH}$ and FSH. The minimum detectable concentrations were $0.2 \mathrm{ng} \mathrm{LH} / \mathrm{ml}$ and $2 \mathrm{ng} \mathrm{FSH} / \mathrm{ml}$. Plasma concentrations of progesterone were measured in one assay using a double-antibody RIA described by Heyman et al. (1984). The intraassay coefficient of variation and the sensitivity of the assay were $<10 \%$ and $0.2 \mathrm{ng} / \mathrm{ml}$ respectively.

Data analysis. Basal concentration, frequency and amplitude of gonadotrophin episodic release (pulses) in individual profiles of the serial sampling period were determined by the PULSAR program (Merriam \& Wachter, 1982). G values which specify the number of assay coefficients of variation over a smoothed baseline that $1,2,3,4$ or 5 consecutive elevated points must be to qualify as a pulse were $G(1)=3 \cdot 8, G(2)=2 \cdot 0, G(3)=1 \cdot 5, G(4)=1 \cdot 2$, and $\mathrm{G}(5)=1 \cdot 0$. Data were assessed statistically by analysis of variance appropriate for repeated measurements using the general linear models (GLM) procedures (SAS, 1987). A logarithmic transformation was applied to the data, if necessary, to equalize variance. Some ewes presented 0 pulses $/ 7 \mathrm{~h}$, and therefore LH pulse frequencies were transformed by adding 0.5 to the number of pulses observed in each sampling period for each ewe, and were subjected to square-root transformation before analysis.

\section{Results}

The mean ( \pm s.e.m.) number of $C L$ per ewe noted at laparotomy was $1 \cdot 8 \pm 0 \cdot 4$ (range $1-3$ ) in Group $C$ ewes and $1.6 \pm 0.3$ (range $1-2$ ) in Group $L$ ewes. The mean ( \pm s.e.m.) duration of gestation was $148.2 \pm 1.0$ (range 146-151) in Group C ewes and 149.0 \pm 1.0 (range 147-152) in Group L ewes.

The mean ( \pm s.e.m.) plasma concentration of progesterone at Day 140 of pregnancy was $8.6 \pm 0.7$ and $10.3 \pm 1.6$ in Group $C$ and $L$ ewes respectively, and these values were not significantly different. In the two groups of ewes, concentrations of progesterone remained below the sensitivity of the assay $(<0.2 \mathrm{ng} / \mathrm{ml})$ during the first 20 days post partum.

There was no significant difference between Group $\mathrm{C}$ and $\mathrm{L}$ ewes in the mean plasma concentrations of LH at Day 140 of pregnancy (Fig. 1). Concentrations of LH were significantly greater at Day 5 post partum than at Day 140 of pregnancy in Group C ewes $(P<0.01)$ and in Group L ewes $(P<0.001)$. In the two groups of ewes, plasma concentrations of LH between Days 5, 10, 15 and 20 post partum were not significantly different but were greater $(P<0.01)$ in Group L ewes than in Group C ewes (Fig. 1).

Mean basal concentrations of LH on Days $5,10,15$ and 20 post partum were significantly greater than at Day 140 of pregnancy in Group C ewes $(P<0.05)$ and in Group L ewes $(P<0.01)$. There were significantly higher basal concentrations of $\mathrm{LH}$ on Days 5,15 and 20 post partum in Group L ewes than in Group C ewes (Fig. 2; Table 1).

The frequency of LH pulses was significantly higher on Days 5, 10, 15 and 20 post partum than at Day 140 of pregnancy in Group C ewes $(P<0.02)$ and Group L ewes $(P<0.001)$ (Table 1). The 

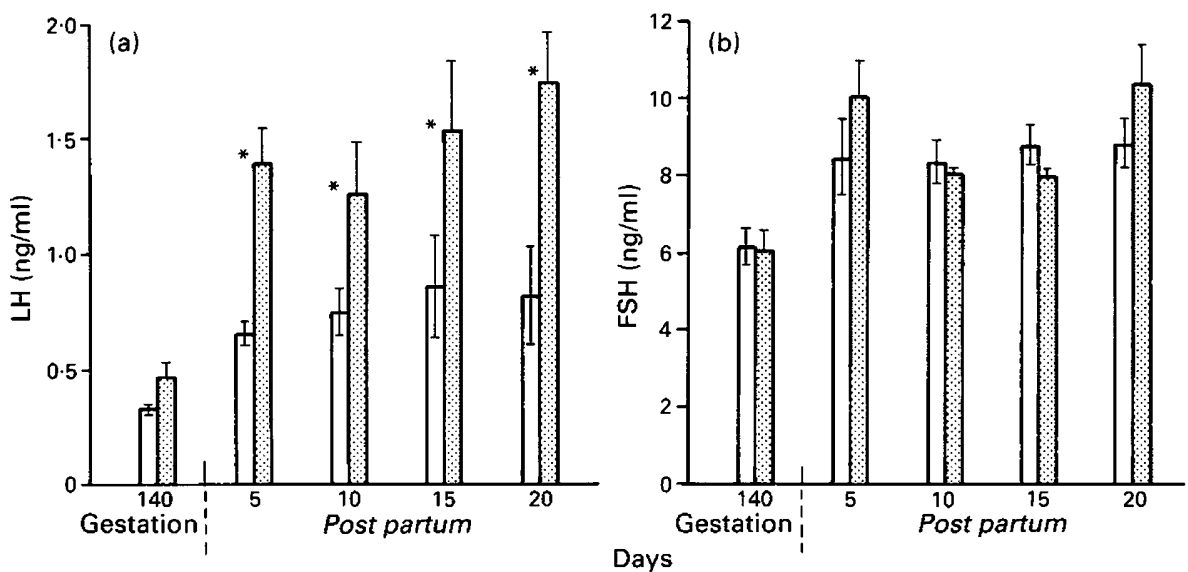

Fig. 1. Mean ( \pm s.e.m.) plasma concentrations of (a) LH and (b) FSH before parturition and during the early post-partum period for 5 intact ewes (Group C) and 5 ewes from which the CL was removed at Day 70 of pregnancy (Group L). ${ }^{*} P<0.01$ compared with values for Group $C$ ewes.

frequencies of $\mathrm{LH}$ pulses for the 4 post-partum stages examined were significantly greater $(P<0.02)$ in Group L ewes than in Group C ewes (Table 1).

The amplitude of LH pulses was significantly higher on Days $5(P<0.01)$ and $20(P<0.05)$ post partum in Group $\mathrm{L}$ ewes than in Group $\mathrm{C}$ ewes (Table 1). There were significantly more $\left(P<0.01 ; \chi^{2}\right.$ test) LH pulses of amplitude greater than $2.07 \mathrm{ng} / \mathrm{ml}$ (the overall mean amplitude on Days $5,10,15$ and 20 post partum) in Group L ewes than in Group C ewes on Days $5(44 \%$ vs $0 \%)$ and $20(70 \%$ vs $20 \%)$ post partum.

There were no significant differences between the two groups of ewes in the mean plasma concentrations of FSH at Day 140 of pregnancy and in any of the 4 post-partum stages examined

Table 1. Characteristics of $\mathrm{LH}$ secretion before parturition and during the early post-partum period for 5 intact ewes (Group C) and 5 ewes from which the CL was removed at Day 70 of pregnancy (Group L)

\begin{tabular}{|c|c|c|c|c|c|c|}
\hline & \multicolumn{2}{|c|}{$\begin{array}{l}\text { Basal conc. } \\
(\mathrm{ng} / \mathrm{ml})^{*}\end{array}$} & \multicolumn{2}{|c|}{$\begin{array}{l}\text { Pulse frequency } \\
\text { (pulses } / 7 \mathrm{~h}) \dagger\end{array}$} & \multicolumn{2}{|c|}{$\begin{array}{l}\text { Pulse amplitude } \\
\text { (ng/ml) } \ddagger\end{array}$} \\
\hline & Group C & Group L & Group C & Group L & Group C & Group L \\
\hline $\begin{array}{l}\text { Day } 140 \text { of } \\
\text { pregnancy }\end{array}$ & $0.32 \pm 0.02$ & $0.43 \pm 0.04$ & $0.40 \pm 0.24$ & $0.40 \pm 0.40$ & $0.34 \pm 0.08$ & $0.98 \pm 0.52$ \\
\hline $\begin{array}{c}\text { Days post partum } \\
5 \\
10 \S \\
15 \\
20\end{array}$ & $\begin{array}{l}0.42 \pm 0.03 \\
0.51 \pm 0.05 \\
0.58 \pm 0.12 \\
0.62 \pm 0.13\end{array}$ & $\begin{array}{l}0.94 \pm 0.11 \\
0.77 \pm 0.26 \\
1 \cdot 12 \pm 0.28 \\
1.38 \pm 0.24\end{array}$ & $\begin{array}{l}2.60 \pm 0.24 \\
1.40 \pm 0.24 \\
1.80 \pm 0.58 \\
2.00 \pm 0.54\end{array}$ & $\begin{array}{l}3 \cdot 20 \pm 0.20 \\
3 \cdot 00 \pm 0.40 \\
3 \cdot 20 \pm 0.58 \\
3.40 \pm 0.50\end{array}$ & $\begin{array}{l}1.11 \pm 0.11 \\
1.93 \pm 0.28 \\
1.99 \pm 0.38 \\
1.35 \pm 0.22\end{array}$ & $\begin{array}{l}2.24 \pm 0.27 \\
2.44 \pm 0.44 \\
2.25 \pm 0.30 \\
2.51 \pm 0.25\end{array}$ \\
\hline
\end{tabular}

Values are mean \pm s.e.m.

*Basal concentrations of LH were significantly greater in Group L ewes than in Group C ewes on Days $5(P<0 \cdot 01)$, $15(P<0.05)$ and $20(P<0.01)$ post partum.

†Frequencies of LH pulses were significantly greater $(P<0.02)$ in Group L ewes than in Group C ewes on Days 5,10 , 15 and 20 post partum.

†The amplitude of LH pulses was significantly higher in Group L ewes than in Group C ewes on Days $5(P<0 \cdot 01)$ and $20(P<0.05)$ post partum.

§At Day 10 post partum one ewe in Group L presented a preovulatory LH surge pattern during the whole sampling period. Data for this animal were excluded from analysis. 

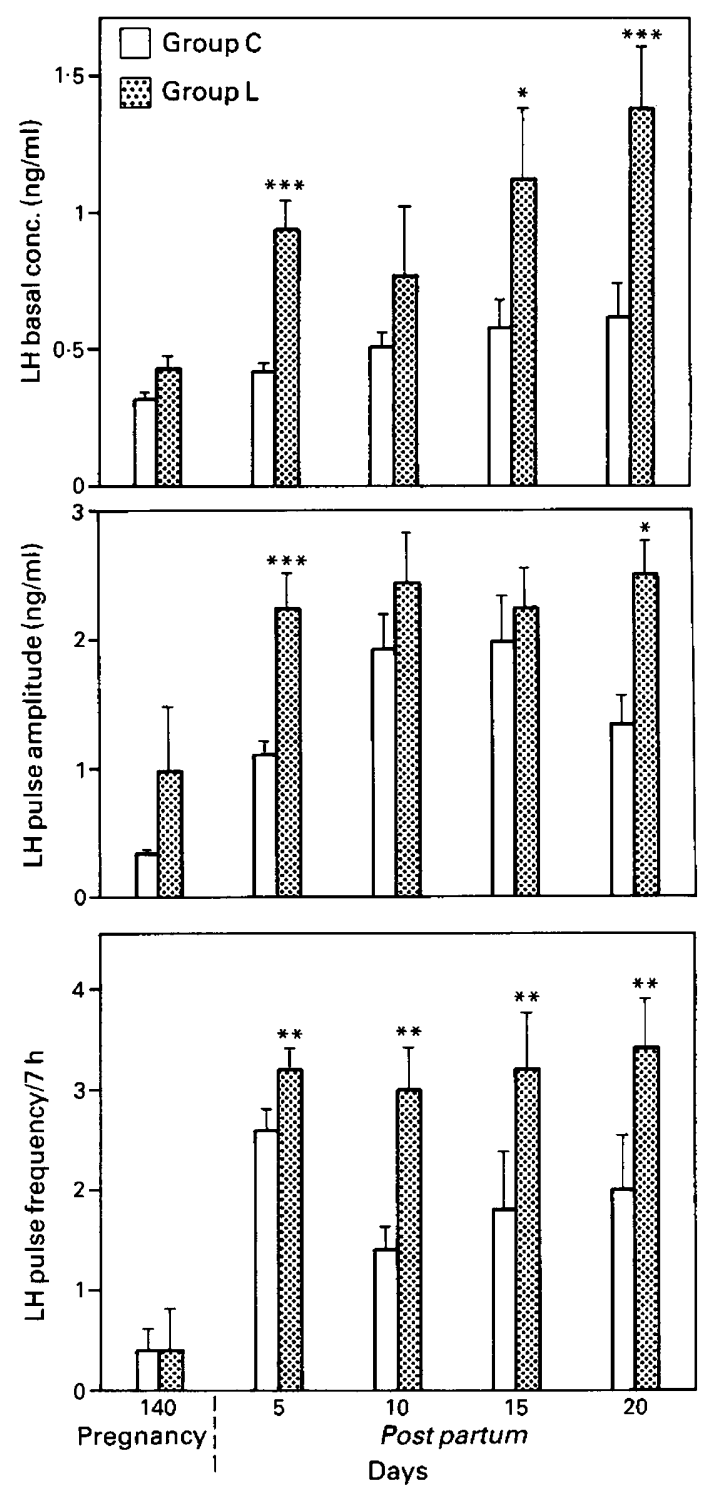

Fig. 2. Characteristics of $\mathrm{LH}$ secretion before parturition and during the early post-partum period for 5 intact ewes (Group C) and 5 ewes from which the CL was removed at Day 70 of pregnancy (Group L). Values are mean \pm s.e.m. ${ }^{*} P<0.05 ;{ }^{* *} P<0.02 ;{ }^{* * *} P<0.01$.

(Fig. 1). Compared to Day 140 of pregnancy, plasma concentrations of FSH in the two groups of ewes increased $(P<0.01)$ during the early post-partum period.

\section{Discussion}

The present study provides the first demonstration about the effect of removal of the CL of pregnancy on the secretion of pituitary gonadotrophins after parturition in ewes. Basal concentrations of $\mathrm{LH}$, frequency and amplitude of $\mathrm{LH}$ pulses in ewes from which corpora lutea were removed at Day 70 of pregnancy increased more rapidly after parturition than in intact ewes, while peripheral 
concentrations of progesterone were undetectable $(<0.2 \mathrm{ng} / \mathrm{ml})$ during the first 20 days post partum in both groups of ewes. These findings are in agreement with those reported by O'Reilly \& Dziuk (1973) who showed that serum and pituitary concentrations of LH increased more rapidly after parturition in ewes which were ovariectomized at Day 28 and pregnancy was maintained until Day 60 with progesterone implants, than in intact ewes. These results and those of the present study are consistent with our previous suggestion that a luteal factor other than progesterone plays a role in the regulation of LH secretion during the last two-thirds of pregnancy (Al-Gubory et al., 1989) and the early post-partum period. The presence of luteal cells in the CL of pregnancy until Day 140 (O'Shea et al., 1979) and at least until Day 15 post partum (O'Shea \& Wright, 1985) in ewes may be involved in the negative control of $\mathrm{LH}$ secretion after parturition.

Antral follicles $>2 \mathrm{~mm}$ in diameter (up to $4 \mathrm{~mm}$ ) are present in ovaries during the luteal phase of the oestrous cycle (Hutchinson \& Robertson, 1966; Brand \& de Jong, 1973) and even during the anoestrous period in non-pregnant ewes (Cahill \& Mauléon, 1980; Cahill et al., 1984). On the basis of a number of studies in the ewe, pituitary gonadotrophins play a major role in the growth of follicles beyond $2 \mathrm{~mm}$ in diameter. Turnbull et al. (1977) and Dott et al. (1979) reported that the population of follicles $>2.5 \mathrm{~mm}$ increased after administration of PMSG. The diameter of the largest follicles does not exceed $2 \mathrm{~mm}$ after hypophysectomy (Dufour et al., 1979; Driancourt et al., 1987) or after immunoneutralization of endogenous GnRH (McNeilly et al., 1986). Antral follicular growth declined progressively during the last two-thirds of pregnancy in ewes (Rüsse, 1971). The diameter of the largest non-atretic and atretic follicles at Day 140 of pregnancy in ewes does not exceed 1 and $1.5 \mathrm{~mm}$ respectively (Al-Gubory \& Martinet, 1986) and this may have resulted from insufficient peripheral concentrations of FSH and/or LH at that time. Al-Gubory et al. (1987) demonstrated that the largest antral follicles at Day 140 of pregnancy never achieved a diameter of $>2 \mathrm{~mm}$ in ovaries from which the CL was removed at Day 70 of pregnancy and in the contralateral ovaries. However, CL excision at Day 70 of pregnancy resulted in a subsequent increase in pulsatile release of $\mathrm{LH}$ while peripheral concentrations of FSH were not changed between Days 60 and 120 (Al-Gubory et al., 1989), and at Day 140 (present study) and were relatively similar to those during the luteal phase of the oestrous cycle in ewes (Cahill et al., 1981). We suggest, therefore, that some extra-ovarian factor(s) associated with pregnancy renders antral follicles refractory to endogenous stimulation of pituitary gonadotrophins, thereby inhibiting further growth of follicles beyond a diameter of $>2 \mathrm{~mm}$. Richards \& Kersey (1979) showed that follicular receptors for $\mathrm{LH}$ and FSH decline progressively during pregnancy in the rat.

The present results show that plasma concentrations of FSH and LH, frequency and amplitude of $\mathrm{LH}$ pulses increased within 5 days after parturition and this could be implicated in the presence of follicles of $>2 \mathrm{~mm}$ in diameter as early as Day 5 post partum (Al-Gubory \& Martinet, 1986). After parturition, the rapid increase of pulsatile release of $\mathrm{LH}$, as shown in the present study, coincides with increasing pituitary LH concentration and release of $\mathrm{LH}$ in response to GnRH (Crowder et al., 1982), concentration of pituitary mRNA for LH $\beta$ - and $\alpha$-subunits (Wise et al., 1985) and receptors for oestradiol (Wise et al., 1986).

We thank Dr J. Fèvre (I.N.R.A., Jouy-en-Josas) for the gift of progesterone antibody; A. Solari (I.N.R.A., Jouy-en-Josas) for assistance in statistical analysis; J. C. Poirier (I.N.R.A., Nouzilly) for expert technical assistance in FSH and LH assays; and P. Bolifraud (I.N.R.A., Jouy-en-Josas) for technical assistance in progesterone assay. This study was supported by grants from the French Medical Research Foundation.

\section{References}

Al-Gubory, K.H. \& Martinet, J. (1986) Comparison of the total ovarian follicular populations at day 140 of pregnancy and at day 5 postpartum in ewes. Theriogenology 25, 795-808.
Al-Gubory, K.H. \& Martinet, J. (1987) Effect of the corpus luteum on ovarian follicular populations and growth in the ewe. Anim. Reprod. Sci. 13, 269-281.

Al-Gubory, K.H., Martinet, J., Paly, J. \& Solari, A. 
(1987) A new concept for control of folliculogenesis during pregnancy in ewes: role of the corpus luteum. Anim. Reprod. Sci. 15, 113-120.

Al-Gubory, K.H., Blanc, M.R., Poirier, J.C., Solari, A. \& Martinet, J. (1989) Evidence that the corpus luteum of pregnancy contributes to the control of tonic secretion of LH in the ewe. J. Reprod. Fert. 85, $125-131$.

Blanc, M.R. \& Poirier, J.C. (1979) A new homologous radioimmunoassay for ovine follicle stimulating hormone: development and characterization. Annls Biol. anim. Biochim. Biophys. 19, $1011-1026$.

Brand, A. \& de Jong, W.H.R. (1973) Qualitative micromorphogical investigations of the tertiary follicle population during the oestrous cycle in sheep. $J$. Reprod. Fert. 33, 431-439.

Cahill, L.P. \& Mauléon, P. (1980) Influence of season, cycle and breed on follicular growth rates in sheep. $J$. Reprod. Fert. 58, 321-328.

Cahill, L.P., Saumande, J., Ravault, J.P., Blanc, M., Thimonier, J., Mariana, J.C. \& Mauléon, P. (1981) Hormonal and follicular relationships in ewes of high and low ovulation rates. J. Reprod. Fert. 62, 141-150.

Cahill, L.P., Oldham, C.M., Cognié, Y., Ravault, J.P. \& Mauléon, P. (1984) Season and photoperiod effects on follicles and atresia in the sheep ovary. Aust. $J$. biol. Sci. 37, 71-77.

Casida, L.E. \& Warwick, E.J. (1945) The necessity of the corpus luteum for maintenance of pregnancy in the ewe. J. Anim. Sci. 4, 34-36.

Crowder, M.E., Gilles, P.A., Tamanini, C., Moos, G.E. \& Nett, T.M. (1982) Pituitary content of gonadotrophins and GnRH-receptors in pregnant, postpartum and steroid-treated ovx ewes. J. Anim. Sci. 54, 1235-1242.

Denamur, R. (1968) Formation and maintenance of corpora lutea in domestic animals. J. Anim. Sci. 27, Suppl. 1, 163-180.

Denamur, R. \& Martinet, J. (1955) Effets de l'ovariectomie chez la brebis pendant la gestation. C. $r$. hebd. Séanc. Acad. Sci. Paris D 149, 2105-2107.

Denamur, R. \& Martinet, J. (1961) Effets de l'hypophysectomie et de la section de la tige pituitaire sur la gestation de la brebis. Annls Endocr., Paris 22, $755-759$.

Dott, H.M., Hay, M.F., Cran, D.G. \& Moor, R.M. (1979) Effect of exogenous gonadotrophin (PMSG) on the antral follicle population in the sheep. $J$. Reprod. Fert. 56, 683-689.

Driancourt, M.A., Fry, R.C., Clarke, I.J. \& Cahill, L.P. (1987) Follicular growth and regression during the 8 days after hypophysectomy in sheep. $J$. Reprod. Fert. 79, 635-641.

Dufour, J., Cahill, L. P. \& Mauléon, P. (1979) Short and long-term effects of hypophysectomy and unilateral ovariectomy on ovarian follicular populations in sheep. J. Reprod. Fert. 55, 301-309.

Ellinwood, W.E., Nett, T.M. \& Niswender, G.D. (1979) Maintenance of the corpus luteum of early pregnancy in the ewe. 1. Luteotrophin properties of embryonic homogenates. Biol. Reprod. 21, 281-288.

Forsyth, I.A. (1973) Secretion of a prolactin-like hormone by the placenta in ruminants. In Le Corps Jaune, pp. 239-255. Eds R. Denamur \& A. Netter. Masson et Cie, Paris.
Heyman, Y., Camous, S., Févre, J., Méziou, W. \& Martal, J. (1984) Maintenance of the corpus luteum after uterine transfer of trophoblastic vesicles to cyclic cows and ewes. J. Reprod. Fert. 70, 533-540.

Hutchinson, J.S.M. \& Robertson, H.A. (1966) The growth of the follicle and corpus luteum in the ovary of the sheep. Res. vet. Sci. 7, 17-24.

Kann, G. \& Denamur, R. (1974) Possible role of prolactin during the oestrous cycle and gestation in the ewe. $J$. Reprod. Fert. 39, 473-483.

Kann, G. \& Martinet, J. (1975) Prolactin levels and duration of post-partum anestrus in lactating ewes. Nature, Lond. 257, 63-64.

Lacroix, M.C. \& Martal, J. (1979) Mise en évidence et évolution d'une gonadotrophine chorionique chez la brebis (oCG). C. r. hebd. Séanc. Acad. Sci., Paris D 288, $771-774$.

Linzell, J.L. \& Heap, R.B. (1968) A comparison of progesterone metabolism in the pregnant sheep and goat: sources of production and an estimation of uptake by some target organs. J. Endocr. 41, 433-438.

Martal, J. (1981) Control of luteal function during early pregnancy in sheep. $J$. Reprod. Fert., Suppl. 30, 201-210.

Martal, J. \& Djiane, J. (1975) Purification of a lactogenic hormone in sheep placenta. Biochem. Biophys. Res. Commun. 65, 770-778.

Martal, J. \& Djiane, J. (1977) The production of chorionic somatomammotrophin in sheep. J. Reprod. Fert. 49, 285-289.

Martal, J. \& Lacroix, M.C. (1978) Production of chorionic somatomammotrophin (oCS), fetal growth and growth of the placenta and the corpus luteum in ewes treated with 2-bromo- $\alpha$-ergocryptine. Endocrinology 103, 193-199.

Martal, J., Lacroix, M.C., Loudes, C., Saunier, M.R. \& Wintenberger-Torrès, S. (1979) Trophoblastin, an antiluteolytic protein present in early pregnancy in sheep. J. Reprod. Fert. 56, 63-67.

Mauléon, P. \& Dauzier, L. (1965) Variation de la durée de l'anestrus de la lactation chez la brebis de race Ilede-France. Annls Biol. anim. Biochim. Biophys. 5, 131-143.

McNeilly, A.S., Jonassen, J.A. \& Fraser, H.M. (1986) Suppression of follicular development after chronic LHRH immunoneutralization in the ewe. $J$. Reprod. Fert. 76, 481-490.

Merriam, G.R. \& Wachter, K.W. (1982) Algorithms for the study of episodic hormone secretion. Am. J. Physiol. 243, E310-E318.

Moor, R.M. (1968) Effect of embryo on corpus luteum function. J. Anim. Sci., Suppl. 1, 97-118.

Moor, R.M. \& Rowson, L.E.A. (1966a) Local maintenance of the corpus luteum in sheep with embryos transferred to various isolated portion of the uterus. J. Reprod. Fert. 12, 539-550.

Moor, R.M. \& Rowson, L.E.A. (1966b) The corpus luteum of the sheep: functional relationship between the embryo and the corpus luteum. J. Endocr. 34, 233-239.

Moore, N.W., Barrett, S. \& Brown, J.B. (1972) Progesterone concentration in maternal and foetal blood plasma of ewes. J. Endocr. 53, 187-194.

Neher, G.M. \& Zarrow, M.X. (1954) Concentration of progestin in the serum of the non-pregnant, pregnant and post-partum ewe. J. Endocr. 11, 323-330. 
O'Reilly, N.W.\& Dziuk, D.J. (1973) Changes in the level of LH in the sera and pituitaries of ovariectomized and intact ewes at parturition. Endocrinology 92, 1575-1578.

O'Shea, J.D. \& Wright, P.J. (1985) Regression of the corpus luteum of pregnancy following parturition in the ewe. Acta anat. 122, 69-76.

O'Shea, J.D., Cran, D.G. \& Hay, M.F. (1979) The small luteal cell of the sheep. J. Anat. 128, 239-251.

Pelletier, J., Kann, G., Dolais, J. \& Rosselin, G. (1968) Dosage radioimmunologique de l'hormone luteinsante plasmatique chez le mouton. Mise au point de la technique de dosage. C. r. hebd. Séanc. Acad. Sci. Paris D 266, 2291-2294.

Restall, B.J. \& Starr, B.G. (1977) The influence of season of lambing and lactation on reproductive activity and plasma LH concentrations in Merino ewes. $J$. Reprod. Fert. 49, 297-303.

Richards, J.S. \& Kersey, K.A. (1979) Changes in theca and granulosa cell function in antral follicle development during pregnancy in the rat: gonadotropin receptors, cyclic AMP and estradiol-17ß. Biol. Reprod. 21, 1185-1201.

Ricketts, A.P. \& Flint, A.P.F. (1980) Onset of synthesis of progesterone by ovine placenta. J. Endocr. 86, $337-347$.
Rowson, L.E.A. \& Moor, R.M. (1967) The influence of embryonic tissue homogenate infused into the uterus on life span of the corpus luteum in the sheep. $J$. Reprod. Fert. 13, 511-516.

Rüsse, I. (1971) Grösse des corpus luteum und Follikelanbildung während der Gravidität bei Rind und Schaf. Zuchthygiene 6, 126-134.

SAS Institute Inc. (1987) SAS/STAT Guide for Personel Computers, Version 6. SAS, Cary.

Turnbull, K.E., Braden, A.W.H. \& Mattner, P.E. (1977) The pattern of follicular growth and atresia in the ovine ovary. Aust. J. biol. Sci. 30, 220-241.

Wise, M.E., Nilson, J.H., Nejedlik, M.T. \& Nett, T.M. (1985) Measurement of messenger RNA for luteinizing hormone $\beta$-subunit and $\alpha$-subunit during gestation and the postpartum period in ewes. Biol. Reprod. 33, 1009-1015.

Wise, M.E., Glass, J.D. \& Nett, T.M. (1986) Changes in the concentration of hypothalamic and hypophyseal receptors for estradiol in pregnant and postpartum ewes. J. Anim. Sci. 62, 1021-1028.

Received 23 November 1988 